\title{
Populism and Central Bank Independence
}

\author{
Charles Goodhart $^{1} \cdot$ Rosa Lastra ${ }^{2}$
}

Published online: 26 September 2017

(C) The Author(s) 2017. This article is an open access publication

\begin{abstract}
The consensus that surrounded the granting of central bank independence in the pursuit of a price stability oriented monetary policy has been challenged in the aftermath of the global financial crisis, in the light of the rise of populism on the one hand and the expanded mandates of central banks on the other hand. After considering the economic case for independence and the three Ds (distributional, directional and duration effects), the paper examines three different dimensions in the debate of how the rise in populism - or simply general discontent with the status quo - affects central bank independence. Finally, the paper examines how to interpret the legality of central bank mandates, and whether or not central banks have exceeded their powers. This analysis leads us in turn to consider accountability and, in particular, the judicial review of central bank actions and decisions. It is important to have in place adequate mechanisms to 'guard the guardians' of monetary and financial stability.
\end{abstract}

Keywords central bank independence $\cdot$ populism $\cdot$ Mandates $\cdot$ accountability Legitimacy · Judicial Review

'The interface between fiscal and monetary policy is essentially a political economy issue; and the extent to which it should be apolitical is also a political economy issue'. ${ }^{1}$

${ }^{1}$ Reddy (2017).

This paper was first presented at the London Financial Regulation Seminar, LSE, London on 22 May 2017, and then at a policy meeting convened by the OMFIF and CCLS on 23 June 2017.

Rosa Lastra

r.lastra@qmul.ac.uk

1 London School of Economics, London, UK

2 CCLS, Queen Mary University of London, London, UK 


\section{Introduction}

Populism has been in the ascendant in the US, the UK and other European countries, from Poland and Hungary to Turkey. The rise in populism, we argue, has dented the consensus that surrounded the support for central bank independence from the late 1980s to 2008.

The word 'populism' has tended to become a generalised, pejorative term of abuse applied to any political party of the (extreme) right, or left, that does not share the main economic tenets of the liberal, central establishment. But in one of its various, and changing, definitions, e.g. that of "a political or social programme, cause, etc., appealing to the mass of the people", 2 all current political parties are 'populist'.

For the purpose of this paper, however, we would tend to define 'populism' as involving a major disagreement with the central liberal tenet that allowing the free movement of labour, capital and goods and services between nations would be both generally beneficial and desirable in almost all circumstances. Thus, we would define a populist as one wanting to restrict the movements of people, capital, and goods and services between nation states.

We would also suggest a subsidiary definition; this being that a populist, once having been democratically elected, would be a politician who would then seek to remove the checks and balances, generally applied in a democratic state, in order to achieve the objectives upon which he (or she) was originally elected; in other words, an elected politician who then seeks autocratic powers.

Thus, our definition comprises two parts, the first being the control of the movement of factors of production and products across national borders, and the second being a desire to achieve autocratic control over all executive powers of government, once having initially been democratically elected.

Populism has thrived in the aftermath of the global financial crisis, since antiglobalization movements, emboldened by the 'will of the people', have challenged the traditional political landscape. Jean-Jacques Rousseau's social contract theory argued that sovereignty arose from the people, not from the monarch. The individuals are the principal sovereignty-holders and they assemble or aggregate their individual wills into a unity: a general or collective will ('the will of the people'). The holder or bearer of such collective will (to whom individuals transfer their private will for the conduct of certain affairs) is the state, and its decisions require the agreement of the original sovereignty-holders. This is the basis of democratic legitimacy. ${ }^{3}$

\section{The Economic Issues}

Rousseau's Discourse on Inequality and many others since (Thomas Piketty's "Capital in the Twenty-first century" being a significant contemporary contribution (Piketty 2014)) emphasize how wealth and income inequality feed popular discontent (Rousseau 2010). Those that feel disenchanted, with little to lose, will vote, rebel or protest against the 'political establishment'. There is a widespread feeling that the skilled jobs in manufacturing, and elsewhere,

\footnotetext{
$\overline{2}$ The Chambers Dictionary (2006).

${ }^{3}$ Lastra (2015).
} 
have been lost, outsourced to China or overtaken by robots. Even where alternative jobs become available, these are often, relatively unskilled, 'gig' jobs in the service economy, with low pay and competition from immigrants. Not only have median wages for 'blue-collar' workers stagnated over the last few decades, but also such workers, and their families, feel often that they have lost respect. In particular, many of them feel that the liberal elite in the centreleft parties (Democrats in the USA, Labour in the UK), have put concern for ethnic minorities and the extension of foreign aid, globalisation and free trade above local working-class interests. ${ }^{4}$

Against this socio-economic background, populist leaders have pledged to reverse the above set of policies in a way that they claim will bring economic benefits and faster growth to the less-educated and poorer segments of the community. Indeed, in the case of President Trump the fiscal arithmetic will only add up if growth does rise from (slightly under) $2 \%$ per annum to (somewhat) over $3 \%$ per annum.

Meanwhile the economic case for Central Bank independence (CBI) was largely predicated on the belief of a vertical Phillips curve, i.e. that at some 'natural rate' of unemployment, (given by forces such as productivity, the strength of unionized bargaining, etc.), inflation would tend to remain constant; push, (spare capacity), below this natural rate and inflation would continuously accelerate, while above the NAIRU deflation would take hold and deepen. When, e.g. in the 1950s, most economists believed in a downwards sloping Phillips curve, i.e. that you could trade off more (less) inflation against less (more) unemployment (UE) and more (less) growth, exactly where one should try to position oneself on the downwards sloping Phillips curve was, rightly, seen as essentially a political decision.

The concept of the vertical Phillips curve radically changed views. If, in the medium and longer term, an economy could not grow faster by accepting a somewhat higher rate of inflation, then the optimal monetary policies must be to maintain price stability, which indeed would support growth, by removing certain distortions arising from high and uncertain inflation.

The empirical basis for continuing belief in the vertical Phillips curve has, however, weakened. Over the last two decades, or so, levels of unemployment (the pressure of demand) have varied widely, but inflation has remained fairly stable, near $2 \%$. The actual, empirical Phillips curve has become closer to horizontal than to vertical. While this is no doubt largely due to the success of central banks in maintaining their inflation targets, and public expectations thereof, it does raise questions whether the inflationary consequences of seeking to run the economy at a higher pressure of demand, at any rate for a time, would necessarily be so bad; indeed, Janet Yellen of the Board of Governors of the Federal Reserve System raised just such an issue in a speech in 2016. What we see lying ahead is a clash between central banks, concerned for their price stability mandate, as unemployment falls below the assessed 'natural' rate, and populist politicians committed to achieving faster growth, especially of real wages. In the Eurozone (and perhaps Japan) the conflict will be somewhat different; the concern will arise more from the impact of higher interest rates (to restrain inflation) on the fiscal position of the more indebted member states.

\footnotetext{
${ }^{4}$ Goodhart (2017) and Vance (2016). On globalization and populism, see Rodrik (2017).

${ }^{5}$ Yellen (2016). The quote relates to her musing about a temporary 'high-pressure economy'.
} 
Giving central banks independence, with a mandate to achieve price stability, has depended on a belief, and circumstances, that, first, was viewed as separating the achievement of price stability from concerns over growth and unemployment (i.e. the vertical Phillips curve); and, second, was conditional on (public sector) debt ratios being low enough to absorb the fiscal effect of higher interest rates. Both supporting conditions have weakened. So, CBI may become increasingly at risk over the next few decades for underlying economic reasons.

But with monetary policy being expansionary at a time of sluggish growth and nearzero inflation, one might have expected little criticism of central bank policy. Indeed, given that they have often appeared to be 'the only game in town', ${ }^{6}$ one might have expected praise, combined with more criticism of the fiscal authorities. ${ }^{7}$ But that has not generally been the case.

Some of the brickbats flung at central banks have related to the slow tempo of the recovery; others to the possibility that one aspect of the unconventional measures, i.e. negative nominal interest rates may have had a counter-productive effect, e.g. by weakening commercial bank profitability. Perhaps the main general criticism is that the unprecedented low level of nominal and real interest rates has been stimulating over-borrowing, a debt over-hang, which may encourage present expenditures, but at the expense of future fragility and potential crises, i.e. borrowing from the future. But the main reasons for such attacks have related to distributional and directional effects.

Distributional effects have always happened as a result of changes in interest rates (e.g., between creditors and debtors). But Quantitative Easing (QE) and Unconventional Monetary Policies (UMPs) are now seen in the context of the winners and losers of globalization. One reason may be that the trends in nominal and real interest rates over the last three decades have been so large and persistent. Earlier it was probably believed that there would be swings and roundabouts, but that inflation, and both nominal and real interest rates, would fluctuate around a norm; so, temporary benefits to one side, or the other, would in the longer run wash out. This has not happened over the last three decades. While central banks claim, with justification, that the effects of their expansionary policies have not worsened, and may have improved, income inequality, their detractors have responded by claiming that such policies will have worsened wealth inequality, particularly between that section of the young whose parents can help them onto the housing ladder, and the remaining section who can get no such help.

Directional effects relate to $\mathrm{QE}$ and asset purchases having an impact on some particular sectors of the economy, e.g. on the housing market, via purchases of mortgage-related securities. But the argument that central banks should only purchase (safe) government debt is historically naïve. Until the 1930s, under the Real Bills doctrine, the argument was reversed; until then it was the short-term bills of exchange

\footnotetext{
${ }^{6}$ El-Erian (2016).

7 "There is a misleading, but commonly used, phrase about some Central Bank operations having 'quasifiscal' effects. All Central Bank operations on their balance sheet, and to affect the level and pattern of interest rates, have fiscal implications, perhaps especially the most traditional open market operations in Treasury Bills to adjust the official short-term interest rate. But there is now, following on from the post-Global Financial Crisis (GFC) allocation of responsibility for financial stability, and for the manipulation of micro and macroprudential instruments, a far wider allocation of non-traditional operational functions to Central Banks. It has been akin to the opening of Pandora's Box." See Goodhart and Lastra (2015).
} 
of trade and industry that should be the preferred instrument, not government debt. Oddly enough, if directional effects are held to be within the political province, there was no widespread suggestion that the $\mathrm{CB}$ should decide on the quantum of base money to be injected into the economy, and then pass it on to an intermediary, staffed and controlled by the politicians and the Ministry of Finance, who would then decide on whom the recipients should be.

There is, furthermore, yet another D effect, Duration, which has so far not figured much in discussion of central bank policies, but where we expect the discussion to become sharper. QE has drastically been reducing the duration of the consolidated public sector debt, including the CB within the public sector, just at a time when debt management precepts would have suggested that a country would have been well advised to lengthen the duration of its public-sector debt, to take advantage of extraordinarily low interest rates. As interest rates start rising, and the CB has to start paying out great wads of money to the banks holding massively expanded balances with themselves, this latter criticism may become much more vocal.

Of the three Ds, Distribution, Direction and Duration, we expect concerns about the first two to slacken as policy becomes re-normalised, but objections to the third to grow. Imagine the populist outcry as rising nominal rates not only slow growth and employment and raise mortgage costs, but also seem primarily to benefit the cash-flow of banks via interest paid on massively expanded reserves at the central bank!

\section{Democracy and Legitimacy}

It is important to draw a demarcation line between politics and electoral agendas (a changing 'game') and the foundations which underpin our democratic systems (a minimum common denominator for the different parties across the political spectrum). A democracy is based upon a system of checks and balances (division of powers) and respect for the rule of law. It requires independence of the judiciary for it to work, as well as free elections and recognition of certain freedoms and human rights.

To present some of the traditional bastions of democracy, in particular the judiciary and the 'nonconforming' media (free speech), as 'enemies' of the people opens a slippery slope. Attacks on the judiciary - questioning their impartiality - are attacks on the rule of law. There is always a danger in popular mandates that override every other check and balance. History provides a powerful warning against the emergence of regimes where dissent is not permitted or where those who oppose the regime are vilified or threatened (Wolf $2017 \mathrm{a}, \mathrm{b}){ }^{8}$

\footnotetext{
${ }^{8}$ As Wolf writes: "(...) Robespierre, Lenin, Hitler and Mao all applied variants of this phrase [enemies of the people]". See FT, 7 March 2017, Britain plays with fire over Brexit. In the context of the approval of the EU (notification of withdrawal) Bill, Liberal Democrat Lord Taverne attacked that 'a dangerous step' towards the doctrine that "the people's will must always prevail". That, he said, was the doctrine favoured by Hitler, Mussolini and Stalin. Wolf in another article "The economic origins of the populist surge" (FT, 28 June 2017) states: 'Populists distrust institutions, especially those that constrain the "will of the people", such as courts, independent media, the bureaucracy and fiscal or monetary rules. Populists reject credentialed experts. They are also suspicious of free markets and free trade. (...) [T] he financial crisis opened the door to a populist surge".
} 
Moving from these important constitutional and philosophical matters to the theme of our paper, we can identify at least three dimensions in the debate of how the rise in populism - or simply general discontent with the status quo - affects central bank independence.

First, the dimension of legitimacy. Legitimacy pre-exists and is a requisite of accountability. Legitimacy in turn is rooted in the concept of sovereignty. ${ }^{9}$ There are two aspects to legitimacy: formal and societal. ${ }^{10}$ According to the former, the creation of an independent central bank must be the fruit of a democratic act: an act of the legislator, a constitutional decision or a treaty provision (non-democratic regimes also have a notion of formal legitimacy embedded in their systems). 'Societal' legitimacy refers to the support by the public, and is determined by the acceptance of, or loyalty to, the system. Of course, societal legitimacy can be fickle since public acceptance is also influenced by politics, the media, current events, changes in circumstances, sentiment, and other factors. In any case, when societal legitimacy weakens or is no longer present, the law is bound to change.

Any democratic regime can alter the mandate of the central bank following the required normative procedure (a statute for example can always be replaced by another statute; Constitutions and Treaties are more difficult to revise, but they are not immutable).

While the initial legal basis 'legitimizes' the establishment of the independent central bank, it cannot by itself legitimize on an ongoing basis the exercise of the powers delegated to such agency. It is then in the continuing life of that entity that accountability becomes necessary to ensure legitimacy. An accountable central bank must give account, explain and justify the actions or decisions taken, against criteria of some kind, and take responsibility for any fault or damage.

Compared with other government agencies, central banks are very powerful entities since they are guardians of monetary stability (and financial stability) and dictate price levels, influencing the level of risk-taking in the economy. ${ }^{11}$ Central banks' monetary policies also have important redistributive effects. That is why accountability is of the essence.

Central banks are not majoritarian, democratic institutions. Central banks are, instead, technocratic bureaucracies, staffed by career employees and, typically, a few leaders elected by the political authorities. It might be said that any bureaucratic agency is non-majoritarian... But the problem is greatly exacerbated in the case of central banks as compared with typical bureaucracies. Central banks do not simply administer a technical regulatory scheme affecting discrete industries or interests. They regulate price levels, which is one of the most fundamental powers of government, and one of the most important practical concerns of the public at large. $^{12}$

\footnotetext{
${ }^{9}$ The attributes of sovereignty are not fixed. As Jackson (2003) noted in his seminal contribution - sovereignty moves through a 'vertical ladder' and 'horizontally' from, and through, different power bases.

${ }^{10}$ See Lastra, above note 4, pp. 84-85, and Verhoeven (2002).

${ }^{11}$ See C-62/14 Peter Gauweiler and Others vs Deutscher Bundestag [2014] OJ C129/11, paragraph 110: "Moreover, the conduct of monetary policy will always entail an impact on interest rates and bank refinancing conditions, which necessarily has consequences for the financing conditions of the public deficit of the Member States".

${ }^{12}$ Lastra and Miller (2001).
} 
Secondly, the mandate. The agreement on the goal (price stability and/or financial stability) provides the justification for CBI, given the 'instrumental' nature of independence. Independence is an instrument to achieve a goal or set of goals. The importance of the goal is therefore the key consideration in designing an adequate legal framework for its pursuit. Some German commentators referred to the arrangement that governed the Bundesbank - namely a price stability oriented monetary policy conducted by an independent central bank - as a constitutive element of 'Ordnungspolitik', of the economic and political order that should be a common denominator accepted by different political parties.

Questioning the goal also leads to questioning specific central bank policies, actions or decisions taken to achieve such goal/s, for example $\mathrm{QE}$ and other unconventional instruments of monetary policy.

When a central bank has several goals, for example, the US Federal Reserve System, the central bank can change policies more easily than when a central bank has a narrowly defined goal, as is the case of the European Central Bank or before 1999 of the Bundesbank. The existence of several unranked objectives - or an unspecific mandate - complicates the exercise of performance accountability.

With expanded mandates, central banks require new mechanisms of accountability (Balls et al. 2016). ${ }^{13}$ This has been the subject of much debate given the significant role that central banks have acquired as crisis managers, macro-prudential and microprudential supervisors and, in some cases, as resolution authorities. Lord Acton's dictum lurks in the background. Accountability remains first and foremost a mechanism to prevent the abuse of power.

As the mandate has become fuzzier, broader and more complicated - with unconventional monetary policies and the renewed emphasis on financial stability - the consensus which surrounds the goal/s crumbles and with it the importance of independence diminishes (Khan 2017). ${ }^{14}$ The delegation of macro-prudential supervision and financial stability to the central bank could become more problematical than inflation targetry, because it is so much harder to monitor, and you cannot really tell whether the authorities are on the right track, or not. It is remarkable: (1) that almost all of the criticism of CBs relates to their monetary policy actions, rather than giving them extra powers to achieve financial stability, and (2) that CBs have also been the 'only game in town', ${ }^{15}$ so one might have expected that public concern with inactivity in fiscal policy and supply side measures to have been more vocal, whereas the criticism seems to be focussed on the only institution trying to do much. Moreover, an independent central bank - as a specialised technocratic agency - operating without electoral or partisan

\footnotetext{
$\overline{13}$ Balls et al. (2016) advocate the preservation of operational independence, while sacrificing a certain degree of political independence for the sake of legitimacy and accountability. See Balls et al. (2016).

${ }^{14}$ As noted by Münchau, writing in the FT, 20 February 2017, 'Central bank independence losing its lustre'): "Once the consensus about the goals of monetary policy breaks down, the notion of central bank independence becomes harder to defend on democratic grounds".

In the case of the ECB the mandate has not been amended (there is a clear hierarchy that has been preserved intact) and the tension comes from the expectations of the citizens, that want more from the central banks.

In a recent IMF Working Paper (WP/17/101), entitled "Central Bank Legal Frameworks in the Aftermath of the Global Financial Crisis", Khan examines the central banks in a selected number of jurisdictions (the only EU country included is France) and it is rather surprising to see in page 28 how little difference there is de iure before and after the 2014 update. His analysis however does not include the US, the UK and the EU generally, where major legal changes have taken place following the crisis.

15 Above note 6 .
} 
influences or constraints can do a better job at preserving monetary and financial stability than a political authority that seeks re-election and is thus subject to time inconsistency problems.

Paul Tucker has explored the challenges to CBI and the contours of macroprudential policy in a recent paper (Tucker 2017). ${ }^{16}$ He urges 'the central banking community not to become too powerful' and suggests that stability policy should focus on a 'standard of resilience' (tolerance to crisis) rather than 'managing the credit cycle'. It would be interesting to see whether some composite rating (akin to CAMEL for micro prudential supervision in the US) could be developed for financial stability purposes - independently from the central bank - and such a rating could then be applied as a standard of resilience. He differentiates between 'regulatory policy' (which is open to challenge in courts) and 'balance sheet policy' (which is less likely to be challenged in courts but may expose the state to fiscal risks). He warns central banks about becoming 'overmighty citizens' and points out that the heavy lifting of sustainable economic recovery is in the hands of governments (not central banks), since only they can remove obstacles to greater dynamism in the supply side of the economy.

Vitor Constâncio has also considered the contours of macro-prudential policy (Constâncio 2017), ${ }^{17}$ suggesting a further expansion of the 'boundaries' of macroprudential policy beyond the banking sector and into the shadow banking system. While this approach is a reflection of the changing nature of financial markets it also posits the question of where to draw the boundaries. ${ }^{18}$

The question of excessive reach, that is whether central banks have abrogated to themselves powers which are not in the mandate, and the legal interpretation of whether a central bank is abiding by the mandate or exceeding its powers, are fundamental issues in a democratic system.

What is clear is that if the mandate gets overstretched the balance between independence and accountability should tilt towards accountability. This can take many forms: additional disclosure requirements, further parliamentary oversight and judicial scrutiny. And ultimately a change in the law - reflecting the expanded mandate - might be the right course of action in a democracy, since any expansive interpretation of delegated central bank powers within a given legal structure should be limited in time.

Thirdly, the dimension of personnel ('central bankers'). Explicit or implicit attacks on central bankers can provide ammunition to politicians in front of their constituencies and/or in front of the electorate at large. If central bankers (those at the helm of their institution in particular) are perceived as critical of the government in power or if their policies are - rightly or wrongly - blamed as being a constitutive part of the popular discontent that propelled populism or a change of government in the first place, they will be criticised. In the current political and economic climate, it has become expedient to blame those - banks, financiers and also central banks - who are partially held responsible for the crisis and for the loss of living standards of a large segment of the population and who appear to remain largely unpunished. We should however beware

\footnotetext{
16 Tucker (2017).

${ }^{17} \mathrm{https} / / /$ www.ecb.europa.eu/press/key/date/2017/html/ecb.sp170511.en.html.

${ }^{18}$ We have discussed the boundary problem in Goodhart and Lastra (2010) and The Interaction between Monetary Policy and Banking Regulation, above note 7.
} 
of turning central bankers into scapegoats and of unduly restricting the flexibility needed to be able to access the best pool of talent (Giugliano 2015a, b). ${ }^{19}$

Appointment and dismissal procedures are important indicators of legal and de facto central bank independence. ${ }^{20} \mathrm{~A}$ 'pluralistic' appointment procedure aims to avoid politicization. By pluralistic we mean 'diversified' membership of the central bank governing bodies, bringing different views to the conduct of central banking tasks, based upon region, gender, sector and/or expertise. In a geographically decentralized structure of government (such as a federal country), membership on the basis of region is important so as to represent the various interests of various parts of the country (or Union, as in the case of the EU). Indeed, in the case of the ECB, the key positions in the Executive Board, in particular the post of President, should not be tainted by political meddling or positioning of 'key Member States'.

Membership based upon sector refers to the inclusion of the various sectors of the economy: industry, commerce, agriculture. For instance, in the USA, the Federal Reserve Banks have a Board of Directors with nine members each (and the president of each Federal Reserve Bank must be a person of 'tested banking experience'). Of those nine members, three members are known as Class A Directors, who are required to be representatives of the member banks, and may themselves be bankers. Three others are designated as Class B Directors, and must represent industry, commerce, and agriculture in the district and must not be officers, directors, or employees of any bank. The remaining three comprise the Class $\mathrm{C}$ Directors and are appointed by the Board of Governors of the Federal Reserve System. In the UK, the main criterion for membership of the Monetary Policy Committee is expertise in either monetary policy, financial markets, or the running of the economy in general (at the macro or micro level). The ESCB combines a geographic criterion (because of the composition of the European Central Bank and the national central banks) and criteria based on expertise (the members of the Executive Board must be selected among 'persons of recognized standing and professional experience in monetary or banking matters').

Another recommendation is for 'professional independence', which is enhanced by the appointment of qualified candidates, well versed in monetary economics and central banking theory and practice. Professional independence is also safeguarded by the establishment of a list of incompatible or disqualifying activities so as to prevent conflicts of interest. For instance, while in office central bankers should be precluded from simultaneously holding private-sector jobs. Central bank officials should perform their duties on a full-time basis (with the possible exception of academic/university engagements). A central banker should not be simultaneously a financial adviser, an employee or a shareholder of a bank, or a member of parliament, as those occupations would engender conflicts of interests. Central bank officials should also be limited in pursuing private employment in credit and financial institutions for a reasonable period following their term of office. These restrictions are designed to preclude their

\footnotetext{
${ }^{19}$ Giugliano (2015a) Central banks face tricky balancing act, Financial Times, 4 August and Giugliano (2015b) Central Banks: Peak Independence, 8 November.

${ }^{20}$ See pp. 32-35 of Lastra (1996) below note 35, and pp. 70-71 of Lastra (2015), above note 3. In a recent paper Cargill (2016) argues that de facto independence is generally less than de iure independence, primarily because of politicians' control of appointments and ability to place pressure on central banks. While there might be some validity in his position, the argument- focusing mainly on the experience of the Federal Reserve System - could have been developed further.
} 
susceptibility to 'private' incentives while in office. Such provisions are particularly necessary to avoid the 'capture' of the regulator by the regulated institutions (the socalled 'revolving door'). ${ }^{21}$

A further safeguard of professional independence refers to the procedures for dismissal of central bank officials. Grounds for dismissal should be clearly defined in the law, including criminal offence or serious misconduct and permanent incapacity. Grounds for dismissal should not include 'displeasure' with central bank actions, or criticism that the Governor or other members of the governing bodies are not fulfilling their obligations.

The UK Prime Minister, Theresa May, criticised the 'bad side effects' of Bank of England policies at the Conservative conference in October 2016, prompting Governor Mark Carney to declare that he would not 'take instruction' from politicians on how to do his job (Bruce \& Hobson 2016). ${ }^{22}$ Janet Yellen, Fed chair, was criticised during the campaign by the then Republican nominee (now President) Donald Trump (The Economist 2016; Liesman 2016), ${ }^{23}$ leading some commentators to talk about the risk of 'politicisation of the Fed' (Davies 2016). ${ }^{24}$ Marine Le Pen in France (who obtained almost 11 million votes in the recent presidential elections on May 7th, 2017) vowed a "revolution in proximity", promising more decision-making by French people and less by global financial forces and multilateral institutions, while the FN manifesto had called for the re-creation of the French franc (Stothard 2017). ${ }^{25}$

Attacks on central banks or central bankers exceeding their mandate or remit (or not performing their mandate as expected by politicians) are often disguised attacks on central bank independence (Münchau 2017a, b; The Economist 2016). ${ }^{26}$ This can undermine their credibility.

\section{Interpreting the Legality of Central Bank Mandates and Activities}

Interpreting whether a central bank abides by its mandate or exceeds its powers becomes more difficult as the mandate gets fuzzier, broader and more complicated, as we observed above. Since independent central banks have 'room for manoeuvre' within a legal framework, this interpretation entails a delicate balance between how much to 'decide by rule' and how much to 'leave to discretion' (echoing Keynes' words).

When an agency is created, power is not just given away, it is delegated. The 'goal constraint' restricts ex ante what the central bank can and cannot do. Few central banks have goal independence.

\footnotetext{
${ }^{21}$ Lastra, ibid.

${ }^{22}$ See http://uk.reuters.com/article/uk-britain-eu-boe-idUKKBN12E0V0.

${ }^{23}$ See http://www.nbcnews.com/storyline/2016-election-day/trump-said-janet-yellen-should-be-ashamedherself-so-will-n681581 quoting Trump as saying "I think she is very political and to a certain extent, I think she should be ashamed of herself. Because it is not supposed to be that way". A recent FT editorial (16 June 2017) entitled "An Independent Fed has never been more crucial" cautions that "continual political pressure on a central bank can damage its credibility'.

24 Davies (20 November 2016). The FT editorial of 16 June 2017 entitled “An independent Fed has never been more crucial" calls on President Trump to reappoint Yellen and make it clear he will not repeat his earlier criticism of the Fed. $25 \mathrm{https}: / /$ www.ft.com/content/a5519f64-eaeb-11e6-930f-061b01e23655.

${ }^{26}$ Münchau (2016) The End of the Era of Central Bank Independence, Financial Times, 13 November and Münchau (2017) "The Shadow Hanging over Central Bank Control”, Financial Times, 16 April.

See also The Economist, http://www.economist.com/blogs/buttonwood/2016/11/unaccountable-technocratsor-convenient-scapegoats, 17 November 2016. Transparency International EU (2017).
} 
Former Federal Reserve System Chairman Ben Bernanke stated in 2009: 'The Federal Reserve has done, and will continue to do, everything possible within the limits of its authority to assist in restoring our nation to financial stability' while President Draghi proclaimed in 2012 his clarion call that he would do "whatever it takes' ... within the limits of our mandate... They were both aware of the need to act, but to act within the rule of law. Legal provisions can - of course - be stretched... by art of creative, imaginative or expansive interpretation (Draghi 2012).

How much freedom, room for manoeuvre, should central banks have? ${ }^{27}$ What is the scope of the delegation?

Independence in the context of central banking is not absolute, but relative. Independence is freedom from political instruction on the one hand and from financial markets on the other hand (the central bank acts in the public interest while financial market participants are driven by private interests). This double dimension goes hand in hand with their dual role as government's bank and bankers' bank. However, what is considered to be 'lack of dependence' has nuances across central banks, across jurisdictions, across time and across functions. Between full independence and full dependence there is a gradation with various degrees of operational autonomy (etymologically autonomy means the ability to give norms to oneself) and control. The ECB and NCBs in the Eurosystem enjoy a very high degree of independence, as $\mathrm{CBI}$ is protected and enshrined in a Treaty (Article 130) and extends to all the tasks entrusted to the ESCB. ${ }^{28}$ The independence of the Federal Reserve System is statutory and Congress could change the law if it wished as former Presidential candidate Ron Paul suggested in "End the Fed" in 2009. ${ }^{29}$

Central banks have discretion within a framework of rules. The discretionary element is essential for understanding some key central banking functions and policies, notably their lender of last resort role (LOLR). The central bank's discretion in its micro

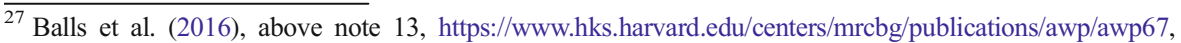
refer to political independence as the absence of any possibility for politicians to influence central bank goals or personnel and operational independence as the ability to choose an instrument to achieve inflation goals. They claim that in order to protect their popular legitimacy, central banks in advanced economies can sacrifice some political independence without undermining the operational independence that is important in both their monetary policy and financial stability functions. See also Forder (2004).

${ }^{28}$ Mersch (2017) in a speech at the ECB on "Central Bank Independence revisited" https://www.ecb.europa. $\mathrm{eu} / \mathrm{press} / \mathrm{key} / \mathrm{date} / 2017 / \mathrm{html} / \mathrm{sp} 170330$.en.html argued that that the rationale of CBI, as set out in the Treaty and interpreted by the CJEU, is to protect the ECB from political influence primarily in the conduct of monetary policy and that micro and macro prudential supervision and crisis management are not protected by the same high level of independence provided by the ECB under Article 130 TFEU. However, we disagree. Neither the content of Article 130 nor the CJEU's interpretation in the OLAF case (at a time when supervision was still national) confine $\mathrm{CBI}$, to monetary policy. $\mathrm{CBI}$ according to the text of Article 130, is applicable to all the tasks conducted by the ESCB ("When exercising the powers and carrying out the tasks and duties conferred upon them by the Treaties and the Statute..."). And the CJEU in the OLAF case adopted a functional interpretation of CBI, arguing that Art. 130 seeks to shield the ECB in the performance of its tasks for all political pressure in order to enable it to effectively pursue the objectives attributed to its tasks.

Zilioli also contends that while the levels of independence and accountability for supervisors and central banks are different, in the case of the ECB Article 130 covers the institution as such and therefore all its activities. Furthermore, according to Article 282.3 TFEU independence is given to the ECB "from the performance of its functions" and there is no distinction neither on the topic, nor on the source (primary or secondary law). See Zilioli (2016).

${ }^{29}$ Paul (2009).
} 
LOLR operations means that no credit institution can be sure of receiving such extraordinary liquidity support. It is up to the central bank to make such a discretionary decision, after determining case by case whether the entity requesting LOLR is sound or unsound. The central bank 'at its own initiative' (Banking Communication 2013) ${ }^{30}$ should provide support to some entities and deny assistance to some others in accordance with the Thornton and Bagehot principles, and increasingly in accordance with published procedures (The Bank of England's Sterling Monetary Framework 2015). ${ }^{31}$

Discretion of course should not mean arbitrariness. It means freedom to act (or not to act) within a framework of rules; and the rules can be changed. Indeed, the discretion of the Fed has been curtailed with regard to its lending to non-banks in the Dodd Frank Act $2010 .{ }^{32}$ Some argue that the rules that frame the discretionary decision should be further enhanced. However, it is important to preserve the flexibility to act swiftly in a crisis. While bilateral LOLR (short-term lending) is discretionary, deposit insurance and resolution proceedings are subject to greater legal constraints than LOLR and generally have a longer time framework.

It is the discretionary element - the uncertainty about whether or not the emergency liquidity assistance will be provided - that reduces the 'moral hazard' that is inherent in any support operation. ${ }^{33}$ Some central banks have been (or remain) secretive when they act as LOLR ('constructive ambiguity') to prevent moral hazard as well as the 'stigma effect' (only the desperate go to the central bank). If accessing central bank credit is perceived as signalling weakness - as was the case with Northern Rock in the UK in September 2007 - instead of LOLR acting as a mechanism to maintain or restore market credibility, news about a bilateral support operation can bring about the very 'bank run' that such support is trying to prevent. ${ }^{34}$

\footnotetext{
${ }_{30}$ That the central bank stands ready to provide liquidity to sound entities does not mean that an entity should 'expect' as an entitlement to receive such assistance. The language 'at its own initiative' is included for example in Commission Communication, 1 August 2013, of State aid rules to support measures in favour of banks in the context of the financial crisis ('Banking Communication') 2013/C 216/01 paragraph 62.

${ }^{31}$ In the USA, the Federal Reserve Act and its implementing Regulation A have provided a framework since the inception of the Federal Reserve System. The main statutory provisions that deal with LOLR under the Federal Reserve Act are: Section 10 (b) for lending to banks; Sections 13(3) and 13(13) for lending to nonbank institutions; and Sections 12 (a) and 14 for open market operations. In the UK, a framework was published in 2013 after the global financial crisis: the Sterling Monetary Framework, http://www. bankofengland.co.uk/markets/Pages/sterlingoperations/redbook.aspx or 'Red Book' comprises: (1) the discount window facility, which is bilateral on demand and firm specific; (2) the indexed long term repo, which is 'market-wide' and aimed at regular and predictable needs for liquid assets; and (3) the contingent term repo facility, which is also 'market wide' but aimed at actual or prospective market wide stress of exceptional nature against the full range of eligible collateral. There is also ELA outside the published framework.

${ }^{32}$ Hal Scott criticises this restriction in the authority under Section 13(3) of the Federal Reserve Act to provide LOLR individual assistance to non-banks only under programmes of broad-based eligibility. See Scott (2015). 33 "Discretion and conditionality on the Eurosystem's non-objection [to ELA] are safeguards against moral hazard”. See Praet (2016).

${ }^{34}$ Hauser (2014). "The stigma associated with being found to be using bilateral central bank support was a significant concern in the UK during the crisis. A relatively modest usage of the Bank of England's regular overnight standing facilities in August 2007, not disclosed by the Bank but rapidly sniffed out by a zealous media, led to febrile speculation about the underlying cause. A month later, the leak of the Bank's ELA to Northern Rock led to a retail run on the bank which had to be stemmed through a blanket government deposit guarantee. (...) What is profoundly clear, however, is that banks prefer, wherever possible, to make use of market-wide rather than bilateral facilities, allowing them to say, "We're all in this together". That is why, across the globe, so much of the heavy lifting in the crisis was done through multilateral operations, in which the total amount provided, and the terms, were often publicly disclosed."
} 
Accountability is not simply an 'add-on' to justify independence. Hence the term 'accountable independence'. ${ }^{35}$ Accountability - ex ante and ex post - is a constitutive part of the design of an independent agency in a democratic system, whose aim is to bring back the central bank to the system of checks and balances, (trias politica).

\begin{abstract}
[I]ndependence is only one side of the coin, for in a democratic community accountability is also necessary. Such accountability should be diversified, dispersed through the three branches of the state, through institutions with differing obligations to the electorate hereby granting the democratic legitimacy that an independent central bank would otherwise lack. This institutional articulation of accountability should be complemented by other forms of accountability, namely public support, disclosure and performance control (...). The optimal trade-off between independence and accountability varies from country to country. ${ }^{36}$
\end{abstract}

Accountability does not necessarily politicize a central bank, rather it means that the central bank should provide a justification of its actions. The institutional design of accountable independence is a balancing act. Too much independence leads to an undesirable state within the state. Too much accountability threatens the effectiveness of independence. When Parliament is dominated by the executive branch of government or when parliamentary accountability is limited (for example the 'monetary dialogue' in the European Parliament) we must rely also on other mechanisms to hold the central bank to account.

A central bank, lest we forget, is both an agency and a bank ${ }^{37}$ and, thus, it needs a special accountability regime.

An accountable central bank should be judged for the reasonableness of its actions, by Parliament, by the executive, by the competent Courts of Justice and by the public. While the debate on accountability has focused primarily on parliamentary scrutiny, performance control and transparency, in the ensuing section we focus on judicial review.

\footnotetext{
${ }_{35}$ Lastra (1992); Lastra (1996); Amtenbrink and Lastra (2008).

${ }^{36}$ Lastra, above note 3, p. 93. "Any recent discussion of accountability often includes a reference to transparency and vice versa. This poses the question of the relationship between the two concepts. Accountability is an obligation to give account of, explain, and justify one's actions, while transparency is the degree to which information on such actions is available. The provision of information is clearly an element of accountability. But accountability is not merely about giving information. It must involve defending the action, policy, or decision for which the accountable is being held to account. The provision of information (transparency) is hardly ever a neutral account of what happened or of what is happening; hence the need for an explanation or justification of the agency's actions or decisions (accountability)."

A recent report on the independence and accountability of the ECB recommends increasing its transparency. See https://transparency.eu/wp-content/uploads/2017/03/TI-EU_ECB_Report_DIGITAL.pdf.

${ }^{37}$ Lastra, above note 3 , chapter 2.
} 


\section{Judicial Review of Central Bank Actions and Decisions}

The judicial review of administrative actions to prevent an arbitrary and unreasonable exercise of discretionary authority is an important element of the rule of law. ${ }^{38}$

Up until the global financial crisis, courts dealt sparsely with central banking actions and decisions..$^{39}$ However, the situation has changed in the last decade on this side of the Atlantic. In the UK, the Northern Rock case led to a lively debate about discretion, financial stability and moral hazard with regard to the LOLR of the Bank of England. ${ }^{40}$ In the EU, with the Pringle case ${ }^{41}$ and the Gauweiler case, ${ }^{42}$ the role of the CJEU in the formation of economic and monetary policy has become the subject of legal and political debate. Before Pringle the only two material ECJ decisions related to EMU were the 2003 OLAF case ${ }^{43}$ which clarified the status and independence of the $\mathrm{ECB}^{44}$ and the 2004 judgment on the Stability and Growth Pact.

When reviewing central bank policies or decisions to assess whether or not a central bank has exceeded its powers, the competent Courts (in the case of the ECB only the Court of Justice of the European Union is competent) may exercise judicial restraint deferring to central bank discretion and expertise - or more robust judicial control. This exercise will vary depending upon which central bank function is at stake, since the contours of discretionary powers are different when it comes to monetary policy than when it comes to banking supervision. ${ }^{45}$ The latter relies on a much more extensive and detailed legal framework than the former. And while central bank accountability with regard to monetary policy has been typically 'explanatory' (unless the law of the central bank is amended or the governor is removed from office, there is little room for

\footnotetext{
$\overline{38}$ The 'rules versus discretion' debate has a long-standing tradition in administrative law. Judicial review of administrative acts is a requirement of a rule of law based system. There are procedural elements that determine the legality of an administrative act, such as the competence of the entity that issues the act or the procedure to prepare and approve such act, and the existence of a public interest. The more difficult issue is the standard of review judges should apply when they conclude that the administrative act they are reviewing is not legal or legitimate and must therefore be changed or substituted.

${ }^{39}$ In the USA, Conti-Brown (2016) notes how "there's no mechanism provided by statute or judicial decision to review Fed actions in court." (Raichle v. Federal Reserve Bank of New York 1929; Scism 2014) ("It would be an unthinkable burden upon any banking system if its open market sales and discount rates were to be subject to judicial review. Indeed, the correction of discount rates by judicial decree seems almost grotesque, when we remember that conditions in the money market often change from hour to hour, and the disease would ordinarily be over long before a judicial diagnosis could be made."). Conti Brown references the decision re AIG in footnote 17 of chapter 4, though that was about the rescue package offered to AIG rather than monetary policy (https://www.wsj.com/articles/trial-in-40-billion-lawsuit-against-aig-bailout-begins1412015133). See also Zaring (2015).

${ }^{40}$ See SRM Global Master Fund LP v The Commissioners of HM Treasury [2009] EWCA Civ 788 and [2009] EWHC 227 (Admin).

${ }^{41}$ C-370/12 Pringle v Government of Ireland [2012] ECLI:EU:C:2012:756.

${ }^{42}$ Case C-62/14 Peter Gauweiler and Others vs Deutscher Bundestag [2014] OJ C129/11.

${ }^{43}$ C- 11/00 Commission of the European Communities v European Central Bank [2003] ECR 1-07147. This case is referred to as 'the OLAF (European Anti-Fraud Office) case'.

${ }_{45}^{44}$ Mersch, https://www.ecb.europa.eu/press/key/date/2017/html/sp170330.en.html above note 28.

${ }^{45}$ Macro-prudential supervision - in the pursuit of financial stability - sits between monetary policy and micro-prudential supervision. In the USA, the designation of a non-bank financial institution as subject to supervision by the Financial Stability Oversight Council is reviewable. The prospective Choice Act, which has now gone through the House of Representatives, which would remove that power altogether. 12 U.S.C. § 5323(b). See Metlife, Inc. v. Fin. Stability Oversight Council, 2016 U.S. Dist. LEXIS 68366 (D.D.C. 2016) (appeal pending).
} 
granting redress with regard to monetary policy decisions), the accountability of the central bank (or other supervisory agencies) in the field of prudential supervision is sometimes 'explanatory' and sometimes 'amendatory'. The liability of supervisory authorities for loss caused by the inadequate supervision of banks ${ }^{46}$ has been discussed in recent years in the context of the BCCI litigation (Lloyd's Rep. Bank 2000; Tait 2006) ${ }^{47}$ and the Peter Paul case. ${ }^{48}$

Central bank discretion (a key component of independence) is the freedom to act within the limits of a legal framework. Judicial review does not extend to the 'content of the decision' (the aim of the Court is not to supplant or replace the decision taken or to second guess what central banks should have done), but it does extend to the parameters and legal framework that surround such decision in order to determine whether or not the central bank mandate has been exceeded. ${ }^{49}$

Discretion in the context of monetary policy means inter alia that the central bank can choose whichever monetary policy instrument it deems appropriate in the pursuit of the goal; discretion also means that the central bank can define what a generic goal such as price stability actually means. The content of such discretionary decision is not reviewable.

Discretion in the context of LOLR is essential for the effectiveness of this function as we discussed above, though such emergency liquidity assistance (ELA) still needs to be provided within the contours of rule-based framework. For example, discretion in the provision of ELA in the Eurosystem means that National Central Banks (NCBs) acting as LOLR in bilateral lending operations (market liquidity assistance via open market operations is the responsibility of the ECB) can choose to provide assistance, or not, to a credit institution (at their own risk and liability), but they must act in accordance with the Treaty provisions (notably Article 123 on the prohibition of monetary financing, Article 127 with regard to the objectives and tasks of the Eurosystem and Articles 130-131 with regard to the principle of central bank independence), the ECB Emergency liquidity assistance

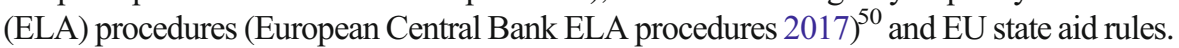

During the twin financial and sovereign debt crisis in the eurozone, the ECB expanded its toolkit of monetary policy instruments into 'unconventional measures.' One of those measures was the Outright Monetary Transactions programme (which was never activated). The OMT programme was announced in a press release

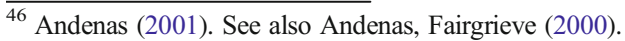

${ }^{47}$ The case against the Bank of England [Three Rivers District Council v. Governor and Company of the Bank of England (No. 3) [2000] 2 W.L.R. 1220; [2000] 3 All E.R. 1; [2000] Lloyd's Rep. Bank. 235, HL was abandoned on 2 November 2005, when BCCI liquidators Deloitte Touche Tohmatsu dropped their claim [against the Bank of England], after receiving a legal ruling that it would not be in the best interests of BCCI's creditors to continue with the lawsuit. See http:/www.ft.com/cms/s/0/5ddffe2a-f68a-11da-b09f-0000779 e2340.html? ft site=falcon\&desktop=true\#axzz4o2zbcMFL.

${ }^{48}$ C-222/02, Peter Paul and Others v. Bundesrepublik Deutschland, [2004] ECR I-(12.10.2004).

${ }^{49}$ The CJEU 'has developed a fairly consistent standard of judicial review of crisis-related measures (...). It comprises a close scrutiny of the purposes of a mandate or competence, a check whether the instruments deployed serve the mandate, and an analysis whether the effects are proportionate to the objectives'. See Goldmann (2016).

${ }^{50}$ The ECB ELA procedures - in accordance with Article 14.4 ESCB Statute - were first published in 2013 and revised in 2014, https://www.ecb.europa.eu/pub/pdf/other/201402_elaprocedures.en.pdf.

A revised version of the ELA procedures, adopted by the Governing Council of the ECB on 17 May 2017 were published on 19 June 2017 and they are available at: https://www.ecb.europa.eu/pub/pdf/other/ Agreement_on_emergency_liquidity_assistance_20170517.en.pdf.
} 
published by the ECB on 6 September 2012 in response to severe financial market tensions in the summer of 2012 (European Central Bank, Technical features of Outright Monetary 2012). ${ }^{51}$ The legality of OMT was challenged by some German citizens (Gauweiler and others) in the German Federal Constitutional Court, Bundesverfassungsgericht, which referred the case to the Court of Justice of the European Union (CJUE) for a preliminary ruling to determine whether the ECB had exceeded its mandate, acting ultra vires, with this announcement.

The CJEU made its final ruling in June 2015, declaring the conditional OMT programme to be legal, since it 'does not exceed the powers of the ECB in relation to monetary policy and does not contravene the prohibition of monetary financing of EU nations, ${ }^{52}$ The CJEU focused on the objectives of monetary policy rather than the effects of the measures under review. ${ }^{53}$

A key feature in the case is the deference to the broad discretion of the ECB. As Advocate General Cruz Villalón stated in his Opinion:

\begin{abstract}
The ECB must accordingly be afforded a broad discretion for the purpose of framing and implementing the Union's monetary policy. The Courts, when reviewing the ECB's activity, must therefore avoid the risk of supplanting the Bank, by venturing into a highly technical terrain in which it is necessary to have an expertise and experience which, according to the Treaties, devolves solely upon the ECB. Therefore, the intensity of judicial review of the ECB's activity, its mandatory nature aside, must be characterised by a considerable degree of caution (Opinion of Advocate General (AG) 2015). ${ }^{54}$
\end{abstract}

The risk of 'supplanting the Bank' justifies the 'degree of caution' that should characterize the intensity of judicial review. "Judges should not overstep the limits of their competences in order to enforce the limits of other actors' competences." ${ }^{56}$ However, the deference to the ECB's 'broad discretion' on the basis of the latter's experience and technical expertise strengthens the case for expertise and adequate preparation of the judges that will assess those complex issues. This happens in other areas of economic regulation. Judicial activism has become the norm in the field of EU competition policy.

\footnotetext{
${ }^{51}$ European Central Bank, Technical features of Outright Monetary Transactions (6 September 2012) http://www.ecb.int/press/pr/date/2012/html/pr120906_1.en.html.

${ }^{52}$ Case C-62/14 Peter Gauweiler and Others vs Deutscher Bundestag [2014] OJ C129/11. The Court also concluded the OMT did not infringe the principle of proportionality.

${ }^{53}$ Tridimas, Xanthoulis (2016): "The emphasis on the objectives rather than the effects of a measure as the determining factor for deciding whether it falls within monetary or economic policy, coupled with a low standard of review, grants the author of the measure enormous discretion".

${ }^{54}$ Opinion of Advocate General (AG) Cruz Villalón in the OMT case, delivered on 14 January 2015 http://eurlex.europa.eu/legal-content/EN/TXT/?uri=CELEX\%3A62014CC0062, paragraph 111. See also paragraph 109. According to Tridimas, Xanthoulis, above note 53, p. 31: "This is a judgment of institutional empowerment (...). The Court was deferential and did not apply a stricter standard of scrutiny."

55 The case against an undesirable 'government of judges' is in line with the separation of powers (trias politica) to which we referred above. In a different context, see inter alia Davis (1987).

${ }^{56}$ Goldmann (2014). Goldmann advocates judicial review on the basis of 'rationality checks' which in his view stand in between 'full judicial review' and 'full discretion'. He also refers to the fact that while the perspective of the Judiciary is 'retrospective', monetary policy involves 'forward-looking' estimates (p. 268).
} 
US Supreme Court Justice Stephen Breyer has argued that it is not possible to understand and evaluate what agencies do without having some sense of the regulatory policy as well. ${ }^{57}$ The need for specific expertise when it comes to the adjudication of complex financial and monetary matters is a relevant issue not only for the CJEU but also, for example, for the UK Supreme Court. If judicial restraint in monetary matters is advocated on the basis of [limited] technical expertise and qualifications of the judges adjudicating such matters, ${ }^{58}$ the counter-argument to not 'being equipped' is to actually equip judges (European Central Bank 2017). ${ }^{59}$

Given the specificity and complexity of monetary policy and other central banking functions (and the added difficulty in the EU context of determining whether a measure is of monetary policy - an exclusive competence of the Union - or economic policy ${ }^{60}$ ) and considering that only the CJEU can judge the ECB (Article 35 ESCB Statute), the need for competence and expertise in the exercise of judicial review could be served by the establishment of a specialised chamber within the CJEU to deal with these issues. Having dedicated specialised judges with expertise in financial and monetary matters when adjudicating cases related to the ECB would enhance the legal framework of ECB accountability in the light of the significantly expanded mandate of the ECB.

\section{Concluding Observations}

The consensus that surrounded the granting of central bank independence in the pursuit of a 'price stability oriented' monetary policy has been challenged in the aftermath of the global financial crisis, in the light of the rise of populism on the one hand and the expanded mandates of central banks on the other hand. After considering the economic case for independence and the three Ds (distributional, directional and duration effects), the paper examined three different dimensions in the debate of how the rise in populism or simply general discontent with the status quo - affects central bank independence. Finally, the paper examined how to interpret the legality of central bank mandates, and whether or not central banks have exceeded their powers. This analysis led us in turn to consider accountability and, in particular, the judicial review of central bank actions and decisions. It is important to have in place adequate mechanisms to 'guard the guardians' of monetary and financial stability.

\footnotetext{
${ }^{57}$ Caplan (2017).

${ }^{58}$ See e.g. Goldmann, above note 56, p. 268 and p. 271.

${ }^{59}$ In the EU context, a specialized court could be created to deal with matters related to the ECB according to Article 257 TFEU and Article 62c of the Statute of the Court of Justice of the European Union.

In her comments to our paper Christina Skinner writes: 'On the issue of specialist courts, a slight variation on your idea: when I was clerking in the Southern District of New York, the judges had pioneered an internal pilot program in which certain judges would self-specialize, by taking on all of one certain type of technical case. For example, one or two judges might take all of the patent cases; another the terrorist sentencing cases. So that could be one way to do it, if you did not want to go all the way to specialist courts.'

${ }^{60}$ Monetary policy is an exclusive EU competence in accordance with Article 3(1)(c) TFEU while economic policy is coordinated at the EU level (positive integration in accordance with Article 119 TFEU and negative integration in terms of the prohibitions applicable to Member States of the eurozone) but the competence remains at the national level. See Lastra, above note 3, Chapters 7 and 8.
} 
Acknowledgements The authors thank Meghnad Desai, Stuart Flemming, Andromachi Georgosouli, Karel Lannoo, Andrea Miglionico, Christina Skinner, Geoffrey Wood, Tim Young and Chiara Zilioli for comments.

Open Access This article is distributed under the terms of the Creative Commons Attribution 4.0 International License (http://creativecommons.org/licenses/by/4.0/), which permits unrestricted use, distribution, and reproduction in any medium, provided you give appropriate credit to the original author(s) and the source, provide a link to the Creative Commons license, and indicate if changes were made.

\section{References}

Amtenbrink F, Lastra R (2008) Securing Democratic Accountability of Financial Regulatory Agencies - A Theoretical framework. In: de Mulder R (ed) Mitigating Risk in the Context of Safety and Security. How Relevant is a Rational Approach? Erasmus School of Law \& Research School for Safety and Security (OMV) 2008, Rotterdam, pp 115-132

Andenas M (2001) Liability for supervisors and depositors' rights: the BCCI and the Bank of England in the house of lords. The Company Lawyer 22:226-234

Andenas M, Fairgrieve D (2000) To supervise or to compensate? A comparative study of state liability for negligent banking supervision. In: Andenas M, Fairgrieve D (eds) Judicial Review in International Perspective. Kluwer Law International, London, The Hague, pp 333-360

Balls E, Howat J, Stansbury A (2016) Central Bank independence revisited: after the financial crisis, what should a model central bank look like? Published as M-RCBG associate working paper no. 67, Harvard Kennedy School of Government

Banking Communication (2013) Communication from the Commission on the application, from 1 August 2013, of State aid rules to support measures in favour of banks in the context of the financial crisis (2013/C 216/01)

Bernanke BS (2009) Federal Reserve Policies to ease credit and their implications for the Fed's balance sheet, speech at the National Press Club Luncheon, National Press Club, Washington, D.C., https://www. Federalreserve.Gov/newsevents/speech/bernanke20090218a.Htm. Accessed 18 Feb

Bruce A, Hobson P (2016) BoE's carney pushes back against criticism from PM may. Reuters http://ukreuterscom/article/uk-britain-eu-boe-idUKKBN12E0V0 Accessed 14 Oct

C- 11/00 Commission of the European Communities v European Central Bank (2003) ECR 1-07147

C-222/02, Peter Paul and Others v. Bundesrepublik Deutschland (2004) ECR I-(12.10.2004)

C-370/12 Pringle v Government of Ireland (2012) ECLI:EU:C:2012:756

C-62/14 Peter Gauweiler and Others vs Deutscher Bundestag (2014) OJ C129/11

Caplan L (2017) A workable democracy. The optimistic project of Justice Stephen Breyer. Harvard Magazine, p. 51

Cargill T (2016) The myth of central Bank independence. Mercatus Working Paper, George Mason University

Chambers Dictionary (2006) Chambers, London, p 1182

Constâncio V (2017) Macroprudential policy in a changing financial system. Second ECB Macroprudential Policy and Research Conference, Frankfurt am Main, https://www.ecb.europa.eu/press/key/date/2017 /html/ecb.sp170511.en.html. Accessed 11 May 2017

Conti-Brown P (2016) The power and independence of the Federal Reserve. Princeton University Press, New Jersey, p 9

Davies G (2016), Trump and Yellen: the politicisation of the fed. Financial Times, https://wwwftcom/content/e26c610 e-1d2c-3f32-970e-b40baeec22c9 Accessed 20 Nov.

Davis MH (1987) A government of judges: an historical re-view. Am J Comp L 35:559-580

Draghi M (2012) Speech at the global investment conference in London. https://wwwecbeuropaeu/ press/key/date/2012/html/sp120726enhtml Accessed 26 July

El-Erian MA (2016) The only game in town. Random House LLC, New York

European Central Bank (2017) Agreement on emergency liquidity assistance. https://wwwecbeuropaeu/pub/ pdf/other/Agreement_on_emergency_liquidity_assistance_20170517enpdf. Accessed 17 May

European Central Bank ELA procedures (2017) https:/www.ecb.europa.eu/pub/pdf/other/Agreement_on emergency_liquidity_assistance_20170517.en.pdf?23bb6a68e85e0715839088d0a23011db. Accessed 17 May

European Central Bank, Technical features of Outright Monetary Transactions (2012) http://www.ecb. int/press/pr/date/2012/html/pr120906_1.en.html. Accessed 6 Sept

Forder J (2004) Central Bank Independence. In: Arestis P, Sawyer M (eds) The rise of the market. Edward Elgar, London Chapter 6

Giugliano F (2015a) Central banks face tricky balancing act, financial times. 4 August 
Giugliano F (2015b) Central Banks: Peak Independence. Financial Times, 8 November

Goldmann M (2014) Adjudicating economics? Central Bank independence and the appropriate standard of judicial review. German L.J. 15, p. 280

Goldmann M (2016) Constitutional pluralism as mutually assured discretion. Maastricht J Eur Comp Law 23:125

Goodhart D (2017) The road to somewhere: the populist revolt and the future of politics. Hurst Publishers, London

Goodhart C, Lastra R (2010) Border Problems. JIEL 13:705-718

Goodhart C, Lastra R (2015) The Interaction between Monetary Policy and Banking Regulation, report prepared at the request of the European Parliament ahead of the Monetary Dialogue with President Draghi, p 37 http://www.europarl.europa.eu/cmsdata/105462/IPOL_IDA(2015)563458_EN.pdf. Accessed 16 June 2017

Hauser A (2014) BIS paper No. 79, p. 89. http://www.bis.org/publ/bppdf/bispap79.pdf

Jackson J (2003) Sovereignty-modern: a new approach to an outdated concept. AJIL 97:782-802

Khan A (2017) Central Bank legal frameworks in the aftermath of the global financial crisis. IMF working paper no. 17/101

Lastra R (1992) The independence of the European system of central banks. Harv IntlLJ 33:475-519

Lastra R (1996) Central banking and banking regulation, chapter 1. Financial Markets Group, London School of Economics, London

Lastra R (2015) International Financial and Monetary Law. Oxford University Press, Oxford, p 9

Lastra R, Miller G (2001) Central Bank independence in ordinary and extraordinary times. In: Kleineman J (ed) central Bank independence. The economic foundations, the constitutional implications and democratic accountability, The Hague, Boston: Kluwer law international, p. 159

Liesman S (2016) Trump said Janet Yellen should be 'ashamed of herself'. So, will she resign? http://www. Nbcnews.Com/Storyline/2016-election-day/trump-said-janet-yellen-should-be-ashamed-herself-so-willn681581. Accessed 9 Nov.

Lloyd's Rep Bank 235 (2000) NLJR 769

Mersch Y (2017) Central Bank independence revisited. https://wwwecbeuropaeu/press/key/date/2017 /html/sp170330enhtml Accessed 30 March

Metlife, Inc. v. Fin. Stability Oversight Council (2016) U.S. Dist. LEXIS 68366 (D.D.C. 2016) (appeal pending)

Münchau W (2016) The end of the era of central Bank independence. Financial Times, 13 November

Münchau W (2017a) The shadow hanging over central Bank control. Financial Times, 16 April

Münchau W (2017b) Central bank independence losing its lustre. Financial Times, 20 February

Opinion of Advocate General (AG) (2015) Cruz Villalón in the OMT case. delivered on 14 January 2015 http://eur-lex.europa.eu/legal-content/EN/TXT/?uri=CELEX\%3A62014CC0062

Paul R (2009) End the fed. Grand Central Publishing, New York

Piketty T (2014) Capital in the Twenty-First Century. Harvard University Press, Cambridge

Praet P (2016) The ECB and its role as lender of last resort during the crisis. https:/wwwecbeuropaeu/press/ key/date/2016/html/sp160210enhtml Accessed $10 \mathrm{Feb}$

Raichle v. Federal Reserve Bank of New York (1929) U.S. Court of Appeals for the Second Circuit, 34 F.2d 910 (2d Cir. 1929)

Reddy Y (2017) Fiscal and monetary Interface in India. National Institute of public finance and policy, New Delhi, sixth Dr. Raja J. Chelliah memorial lecture, 24th march, 2017, p 7

Rodrik D (2017) Populism and the economics of globalization, CEPR discussion paper No. 12119. https://drodrik. scholar.harvard.edu/files/dani-rodrik/files/populism_and_the_economics_of_globalization.pdf

Rousseau J (2010) Discourse on inequality. Kessinger Publishing, Whitefish

Scism L (2014) Trial in $\$ 40$ billion lawsuit against AIG bailout begins. https://wwwwsjcom/articles/trial-in40-billion-lawsuit-against-aig-bailout-begins-1412015133 Accessed 29 Sept

Scott H (2015) The Federal Reserve: the weakest lender of last resort among its peers. Int Financ 18:321-342

SRM Global Master Fund LP v The Commissioners of HM Treasury (2009) EWCA Civ 788 and [2009] EWHC 227 (Admin)

Stothard M (2017) Marine Le Pen launches presidential campaign. Financial Times, 4 February

Tait N (2006) Costs settlement brings to an end record-breaking BCCI litigation. Financial Times, http://www.ft. $\mathrm{com} / \mathrm{cms} / \mathrm{s} / 0 / 5 \mathrm{ddffe} 2 \mathrm{a}-\mathrm{f} 68 \mathrm{a}-11 \mathrm{da}-\mathrm{b} 09 \mathrm{f}-0000779 \mathrm{e} 2340$.html?ft_site=falcon\&desktop=true\#axzz4o2zbcMFL

The Bank of England's Sterling Monetary Framework (2015) http://www.bankofengland.co. uk/markets/Documents/money/publications/redbook.pdf

The Economist (2016) Rethinking central bank independence. https://wwweconomistcom/blogs/buttonwood/2016 /11/unaccountable-technocrats-or-convenient-scapegoats Accessed 17 Nov 
Three Rivers District Council v. Governor and Company of the Bank of England (No. 3)[2000] 2 W.L.R. 1220; [2000] 3 All E.R

Transparency International EU (2017) Two Sides of the Same Coin? Independence and Accountability of the European Central Bank, https://transparency.eu/wp-content/uploads/2017/03/TI-EU_ECB_Report_ DIGITAL.pdf

Tridimas T, Xanthoulis N (2016) A legal analysis of the Gauweiler case. Maastricht J Eur Comp Law 23:38

Tucker P (2017) Financial systems and the real economy. BIS papers no. 91

Vance J (2016) Hillbilly elegy: a memoir of a family and culture in crisis. Harper Collins Publishers, New York

Verhoeven A (2002) The European Union in search of a democratic and constitutional theory. The Hague, Kluwer law international, London and New York, pp. 10-11 and 364

Wolf M (2017a) Britain plays with fire over Brexit. Financial Times, 7 March

Wolf M (2017b) The economic origins of the populist surge. Financial Times, 28 June

Yellen J (2016) Macroeconomic research after the crisis. Speech delivered at the 60th annual economic conference on "the elusive 'great' recovery: causes and implications for future business cycle dynamics", sponsored by the Federal Reserve Bank of Boston, Boston, 14 October

Zaring DT (2015) Law and custom on the Federal Open Market Committee. Law and contemporary problems 78, SSRN: https://ssrn.com/abstract=2624111

Zilioli C (2016) The independence of the European Central Bank and its new banking supervisory competences. In: Ritleng D (ed) Independence and legitimacy in the institutional system of the European Union, collected courses for the EUI summer academy 2012. Oxford University Press, Oxford, pp 125-179 